\title{
Városi mobilitás, közjavak, fenntarthatóság
}

\begin{abstract}
A közlekedés új technológiai lehetőségeinek felhasználásán túl a szabályozási módszerek fejlesztésében és a társadalmi elvárások befolyásolásában rejlő tartalékok mozgósítása is nélkülözhetetlen a fenntartható városi közlekedés megteremtéséhez. A tanulmányban a városi közterületek közjószág-tulajdonságait tekintjük át, ahol két kritérium - a kizárás és az akadályoztatás - alapján négy tartományt különítünk el: magánjavakat, tiszta közjavakat, véges készlettel rendelkező közös javakat és feltételes hozzáférésű (vagy klub-) javakat. Ha az akadályoztatási kritériumot a használatsürüséggel arányos, folytonos skálaként kezeljük, megkülönböztethetjük az eltartóképességi határt kijelölő pontot (a hosszú távon fenntartható müködés határa), valamint a hozammaximumot kijelölő pontot. E modell tárgyalási keretül szolgál a fenntarthatatlan városi közterület-használat fenntartható irányba tereléséhez, azaz értékelni tudjuk az igények befolyásolási módszereit vagy az eltartóképesség növelésére irányuló lehetőségeket. A zárórész áttekinti, hogy napjaink legtöbbet tárgyalt közlekedéstechnológiai újdonságai - nevezetesen az elektromos és az önvezető jármü - milyen feltételekkel kapcsolódnak a kívánatos szakpolitikai intézkedésekhez. Az elvárt fenntarthatósági előnyöket csak szervezett, integrált városi közlekedési rendszer keretébe beleillesztett szolgáltatás képes biztosítani.* Journal of Economic Literature (JEL) kód: H4, H41, R4.
\end{abstract}

A mobilitás és a fenntarthatóság kapcsolatában - és általában is a fenntarthatóság összefüggésében - kiemelkedő fontosságú témakör a (közlekedési) kibocsátások limitálásának a szempontja, illetve a felhasznált erőforrások - elsősorban a fosszilis energiahordozók - végessége. A felmerülő problémákra folyamatosan születnek

* A cikk a 21. Közlekedésfejlesztés Magyarországon elnevezésű konferencián (Siófok, 2019. május 14-16.) tartott előadás szerkesztett és bővített változata.

A szerző ezúton köszöni Horváth M. Tamásnak, Juhász Mattiasnak és Vörös Tündének, továbbá a konferencia résztvevői közül Bacsa Jánosnak, Hajnal Tündének, Márkus Ferencnek és Scharle Péternek, valamint a kézirat anonim lektorának hasznos észrevételeit.

Fleischer Tamás, MTA Közgazdaság- és Regionális Tudományi Központ, Világgazdasági Intézet (e-mail: fleischer.tamas@krtk.mta.hu).

A kézirat első változata 2019. július 10-én érkezett szerkesztőségünkbe.

DOI: http://dx.doi.org/10.18414/KSZ.2019.10.1056 
technológiai válaszok az anyaghasználat, a hulladéktermelés és -kibocsátás csökkentése vagy új üzemanyagok, motorok, szürők stb. megjelenése terén.

Mindezzel együtt az a tapasztalat, hogy a forgalom növekedéséből adódó mennyiségi hatás rendre felemészti, sőt meghaladja a technológiai javulással elért fajlagos csökkentés eredményeit. Jól illusztrálja ezt a klímaváltozás szempontjából kiemelt figyelmet élvezö üvegházgázok, illetve a szén-dioxid-kibocsátás trendje. 2016-ban Európában a szén-dioxid-kibocsátás 26,96 százalékát okozta a közlekedés. Ez az ágazat az egyedüli, amelyik mindmáig felette van az 1990-es kibocsátási értékének, mégpedig jelentősen, mintegy negyedével meghaladva azt - miközben a többi ágazat, ha el is marad a párizsi egyezményben rögzített csökkentési célkitűzéstől, de visszafogja kibocsátásait. A közlekedés esetében a kimutatható, közel 27 százalékos kibocsátási aránynál is nagyobb problémát jelent az a tény, hogy az ágazat tendenciájában szembemegy a csökkentési célkitüzésekkel (Todts [2018]).

Ahhoz, hogy a mobilitás eleget tegyen a fenntarthatósági követelményeknek, a technológiai fejlesztések szükségesek, de nem elégségesek. Ezen túlmenően arra is szükség van, hogy a közlekedés szervezésében, szabályozásában, illetve a közlekedéssel kapcsolatos társadalmi elvárásokban is jelentős változások történjenek. Az írás szemléleti összefüggések megvilágításával kíván hozzájárulni ennek elösegítéséhez.

A városi közterület élhetővé tételének időszerü szabályozási lépései a - 20. század folyamán a rendelkezésre álló terület egyre nagyobb részét birtokba vevő, onnan számos tevékenységet kiszorító - gépjármü-közlekedés térigényének és területhasználati módjának felülvizsgálata, a közterületnek a különböző városi funkciók közötti újrafelosztása és e területen a közlekedés összességének integrált mobilitási szolgáltatás formájában történő kezelése.

A vázolt területi problémakör megragadásához a közterületek közjószág-tulajdonságainak a vizsgálatából indulunk ki, kísérletet téve arra, hogy ez a megközelítés szolgáljon a városi tér arányos, méltányos és fenntartható használatát elősegítő lépések rendszerbe foglalásának keretéül. Az alábbiakban elöször a közjavak csoportosítását tekintjük át, a kérdéskörhöz kapcsolva két további fogalmat, a fenntarthatóságot és a kapacitáskihasználtságot. Ezt követi a mobilitás szempontjából releváns - és a fenntarthatóság elősegítésére alkalmas - tennivalók tárgyalása. Külön is kitérünk arra, hogy az új technológiai megoldások mennyiben alkalmasak a fenntartható városi mobilitás elösegítésére; végül pedig néhány nemzetközi példa illusztrálja a szükséges szemléletváltás megindulásának a jeleit és perspektíváját.

\section{Magánjavak, közjavak - elméleti keret}

A magánjavak tulajdonosokhoz kötődnek, esetükben a tulajdonos joga, hogy az őt megillető jószággal (például egy adag élelmiszer) rendelkezzen, míg másokat jogában áll ugyanezen jószág élvezetéből kizárni. Ezzel szemben vannak más javak (például a tiszta levegö), amelyek esetében ilyen kizárásra semmiféle jogi alap nincs (számos esetben fizikai lehetőség sincs). Elhamarkodott lenne ezt az egyetlen kritériumot 
a közjavak meghatározásaként tekinteni, annyi azonban elmondható, hogy a közjavak egyik jellemzője ez a feltétel, azaz a nemkizárhatóság.

A közjavak fogalmának értelmezése hosszú utat járt be az elmúlt hat-hét évtizedben, és még az sem állítható, hogy mára nyugvópontra jutott. A nemkizárhatóság kritériuma is mást jelent a piaci koordináció elsőbbségéből kiinduló közgazdász számára (a nemfizetőket nem lehet vagy nagyon költséges lenne kizárni), illetve a méltányosságot szem előtt tartó döntéshozó vagy társadalom számára (bizonyos javak fogyasztásából nem elfogadható bárkit kizárni). Emellett legalább Samuelson [1954] megjelenése óta világos, hogy a külső szabályozással elérhető kizárási feltétel mellett egy olyan további kritérium is felmerül, amelyik a szereplők egymás közötti viszonyát jellemzi.

$\mathrm{Az}$, hogy egy jószág ténylegesen bárki számára rendelkezésre álljon, két esetben teljesülhet: akkor, ha a használat eleve nem csökkenti mások lehetöségét arra, hogy ők is használják ugyanazt a jószágot (például egy zenemü meghallgatása), illetve ha a jószág olyan bőségben áll rendelkezésre, hogy bárkinek jut belőle (például a levegő). Ez a két eset úgy összegezhető, hogy e javak felhasználói nem akadályozzák egymást a jószág fogyasztásában. ${ }^{1}$

Samuelson idézett cikkében úgy fogalmaz, hogy a közfogyasztási javak „olyan javak, amelyeket a közösség bármely tagja fogyaszthat anélkül, hogy ezzel csökkentené mások fogyasztási lehetőségeit" (Samuelson [1954] 387. o.). ${ }^{2}$ A mai olvasó talán érzi a gondolat hasonlóságát a fenntartható fejlődésre vonatkozó, három évtizeddel későbbi meghatározással: „a fejlődés olyan formája, amely a jelen szükségleteinek kielégítése mellett nem fosztja meg a jövő generációit saját szükségleteik kielégítésének lehetőségétől" (Brundtland-bizottság [1988]). Ez a párhuzamosság mintegy előrevetíti a közjószág kérdéskörének összekapcsolhatóságát a fenntarthatóság szempontjaival, nevezetesen annak nem feltétlenül intergenerációs, hanem az egy időben felmerülö (intragenerációs) viszonyrendszerével.

Jelen írásnak nem célja, hogy átfogó elemzést adjon a közjavak meghatározásának fejlődéséről és a vitatott álláspontokról. Ehelyett azt a kettős kritériumrendszert vesszük alapul, amit föként Buchanan [1965/1992] és Ostrom [2005] nyomán ma széles körben elfogadnak. Eszerint a közjavak ábrázolásánál a két kritériumot (a szabályozással való kizárhatóságot és az egymás akadályozását) független tengelynek tekintve, a sík négy negyedre oszlik. Az 1. ábrán ennek alapján a magánjavak és a közjavak (tiszta közjavak) átellenes térnegyedbe kerülnek, ugyanakkor két további olyan térnegyed is megnyílik, ahol a kizárhatóság, illetve az egymás akadályozása feltételei felemás módon teljesülnek, ezáltal a közjószágjelleg is további mérlegelésre szorul. Az e térnegyedekbe írt megnevezéseket a későbbiekben értelmezzük.

Az ábrázolás arra is alkalmat ad, hogy éles határvonallal elválasztott fogalmak helyett a tengely mentén fokozatosan változó mennyiségként értelmezzük a kritériumokat.

Az „egymást nem akadályozzák-akadályozzák” tengelyen lefelé haladva azonban nem az akadályozás mértéke változik folytonosan, hanem a jószág iránti kereslet

\footnotetext{
${ }^{1}$ Nem rivalizálónak szokták az ilyen feltételt kielégítő javakat nevezni - az akadályoztatás hangsúlyozását érthetőbbnek gondoljuk.

${ }^{2}$ A magyar fordítás forrása Mozsár [2004].
} 
1. ábra

Magánjavak, közjavak csoportosítása és a keresletnövekedés visszahatása

Egymást nem akadályozzák

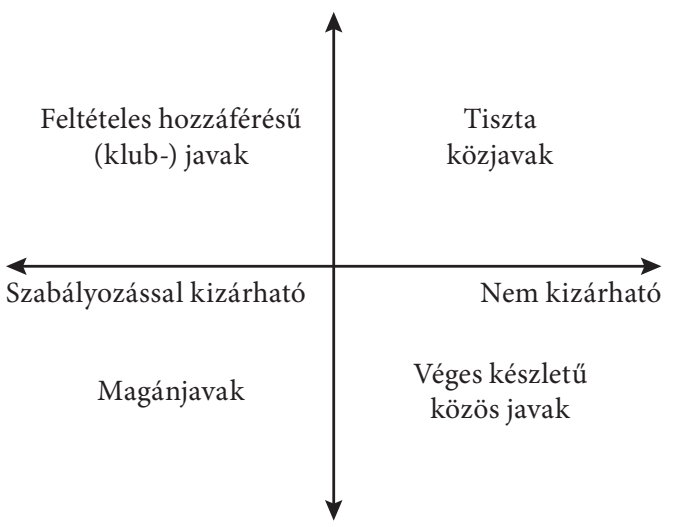

Egymást akadályozzák
Kereslet Fajlagos hozam Összes hozam

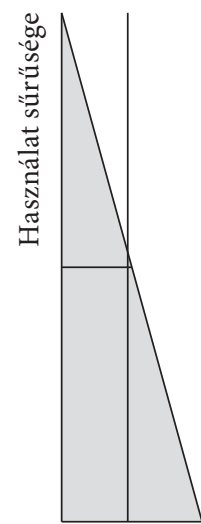

1.a)
Akadályoztatás határa

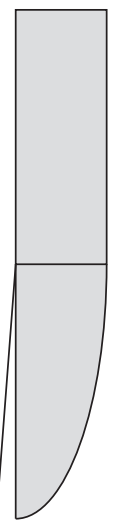

1.b)

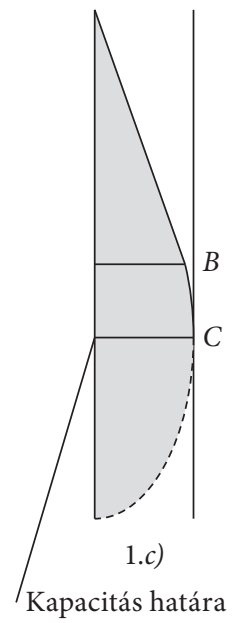

Forrás: saját szerkesztés.

növekedésével a jószágot igénybe vevő használat sűrűsége. Ezt illusztrálja az 1.a) diagram a jószág iránt megmutatkozó kereslet és a használat sűrűsége összefüggésének a bemutatásával. A sürüség növekedése azonban visszahat a közjószágjelleg érvényesülésére: amint elér egy akadályoztatási határt, megszűnik a bőség, ennél nagyobb sürűség esetén a felhasználók már akadályozzák egymást, és átkerülünk a „közlegelők tragédiája” ismert tartományába (Hardin [1968]), amit véges készletü közös javak névvel illethetünk.

A metszéspont fölött a közlegelö még elég füvel szolgál minden tehén számára, így az egyes tehenek tejhozama változatlan marad [1.b) ábra], a metszéspont után viszont egyre kevesebb fü jut, és csökkenni kezd a fajlagos hozam. A következmény többféle lehet. Hardin eredeti példájában 10 tehén 10-10 liter tejet adott a határpont előtt, 11 tehén legeltetése esetén az egyes tehenek hozama 9 literre esett vissza, így az összes hozam is csökkent, 100 literről 99 literre. Ez az eset azonban a modellnek egy határesete, amikor is az akadályoztatás megjelenésekor a közjószág igénybevételének 10 százalékos növekedése 10 százalékos hozamcsökkenéssel jár, azaz e ponton a hozam keresletrugalmassága -1 .

Ha ez a rugalmassági tényező eléri vagy meghaladja az 1-es értéket, akkor - a példához hasonlóan - az akadályoztatási határpont egyben a közösségi hozam optimumát is jelenti. Ha viszont a rugalmassági tényező abszolút értéke kisebb egynél, akkor ez a két pont elválik egymástól. Az 1.c) ábra, a kumulált hozamok diagramja ilyen esetet mutat be, amikor egy darabig még akadályoztatás esetén is tovább nő az összes hozam, egészen a $C$ pontig; azon túl kezd az összes tehén összes tejhozama is csökkenni. Ez utóbbi pont a kapacitás, a kibocsátási volumen határa: ha csak a rövid távon elérhető hozamot tekintjük célnak, akkor ennek a pontnak az elérése látszik kedvezőnek. 


\section{A fenntarthatóság és a kapacitáskorlát értelmezése e keretben}

Az 1. ábra jobb oldali része [1.a)-c) ábra] alkalmas arra, hogy illusztráljuk a fenntarthatóság mibenlétét, és megkülönböztessük a fenntartható termelést a hozammaximalizáló termeléstől. Hiszen a közlegelő példáján azt is érzékelnünk kell, hogy az igénybevétel fokozásakor nemcsak a fajlagos tejhozam csökken, de a tehenek kevesebbet esznek, ami idővel a leromlásukhoz, akár a pusztulásukhoz is vezethet. Az akadályoztatási határként ábrázolt vonal tulajdonképpen az eltartóképesség határvonala: a közlegelő esetében egyszerüen a terület füállománya, általánosabb esetben a természet által biztosított megújuló források összességének, továbbá a természet kibocsátásokat és hulladékokat feldolgozó képességének valamilyen összetett mutatója. Addig fenntartható a rendszerünk, amíg ezt a határt sem a források oldalán, sem a kibocsátások oldalán nem lépjük át. Fentieknek megfelelően az 1.c) ábra azt mutatja, hogy ez a $B$ határpont eltérhet a hozamok maximálása szempontjából kijelölhető, de a hosszú távú fenntarthatóságot nem biztosító $C$ kapacitáshatártól.

A közlegelők tragédiájának modellje alapján mutathatjuk be például azt is, hogyan csökken a városi utak szolgáltatóképessége a forgalom növekedésével, a hálózati kapacitás kimerülésével. Az tehát, hogy egy közút közjószágnak tekinthetö-e vagy nem, nem csupán a létesítménytől és annak jogi szabályozásától függ, hanem az út iránt megnyilvánuló forgalmi igények mértékétől is. Ahogy azt a 2. ábra mutatja, míg két község között vezető út tiszta közjószágként viselkedik, a fizikailag akár hasonló megjelenésü (ugyanolyan széles, ugyanolyan teherbírású, ugyanúgy köztulajdonban lévő) út a városban esetleg már nem felel meg a feltételnek, mivel az iránta támasztott forgalmi igények nagyobbak. A 2. ábra azt is mutatja, hogy egy szintén hasonló műszaki paraméterü út akár magánjószág is lehet, ha például azt az erdészet a saját területén magának építette, és lehet feltételes hozzáférésü jószág is, ha az út használatából kizárnak bizonyos felhasználókat.

2. ábra

Fizikailag hasonló létesítmények eltérő közjószág-kategóriákban

Egymást nem akadályozzák

\begin{tabular}{|c|c|}
\hline $\begin{array}{l}\text { Feltételes hozzáférésü } \\
\text { (klub-) javak }\end{array}$ & $\begin{array}{c}\text { Tiszta } \\
\text { közjavak }\end{array}$ \\
\hline Autóút & Községek közötti út \\
\hline Szabályozással kizárható & Nem kizárható \\
\hline Magánjavak & $\begin{array}{l}\text { Véges készletü } \\
\text { közös javak }\end{array}$ \\
\hline Erdészeti út & Városi út \\
\hline
\end{tabular}

Egymást akadályozzák

Forrás: saját szerkesztés. 
3. ábra

Zavartalan $(A-B)$, zavart $(B-C)$ és torlódott $(C-D)$ forgalom a közúti kapacitás tervezése, illetve a közjavak és fenntarthatóság szerint

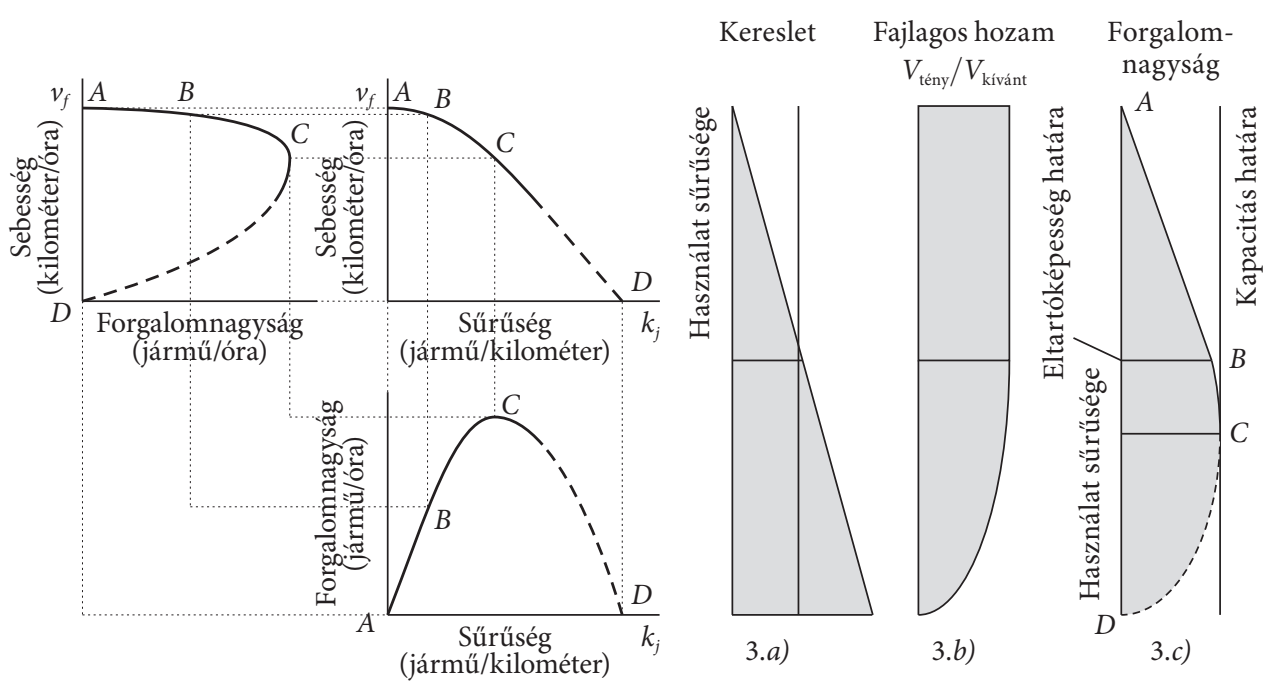

Forrás: Motorway design... [2017] és saját szerkesztés.

A 3.c) ábrán az $A, B, C, D$ betűk választják el a forgalmi igények növekedésével kialakuló, eltérő szolgáltatási szintet biztosító szakaszokat. Az $A-B$ szakasz az akadályozástól mentes, zavartalan forgalom tartománya. A $B$ és a $C$ között az akadályoztatás egyre nö, a forgalom zavart, de az átbocsátott forgalmi mennyiség még nő. A $C$ és a $D$ között a zavarás mértéke tovább nő, ugyanakkor az átbocsátóképesség lecsökken. Az ábra bal oldalán az eredetileg a Highway Capacity Manual [2000] nyomán ismert fundamentális diagramot látjuk, amely a sebesség-sürüség-forgalomnagyság összefüggésben ugyanezt a tagolást érzékelteti. Az $A-B$ szakasz zavartalanságát a sebesség szabad megválaszthatósága jellemzi; az átbocsátóképesség a sürüséggel arányosan nő. A $B-C$ szakasz korlátozza a sebességet, az átbocsátóképesség még nő, de a sűrüségnél kisebb mértékben; míg a $C-D$ szakaszon a sürüség további növekedésével mind a sebesség, mind az átbocsátóképesség drasztikusan csökken.

A 3. ábra két része ugyanannak a jelenségnek a különböző ábrázolása: az eltérés annyi, hogy míg a bal oldali diagram forrása, a közúttervezési kézikönyv (Motorway design... [2017]) nagyobb hangsúlyt helyez a maximális átbocsátóképesség kihasználására, és ezt a $C$-vel jelzett pontot tekinti referenciapontnak (biztonsági ráhagyással ennek 70-80 százalékát javasolva tervezési célnak), addig az ábra jobb oldala, az általunk bemutatott ábrázolás arra hívja fel a figyelmet, hogy a hosszú távú fenntartható müködést egy ennél esetenként szerényebb forgalmat megengedö, a forgalom résztvevőinek a szempontjait alapul vevő $B$ ponti állapot biztosítása jelentheti: mindenesetre referenciapontként erről az oldalról célszerü kiindulni. További részletes szakmai megfontolásokat igényel annak a mérlegelése, hogy egymás zavarásának kezdete (a szabad sebességválasztás megszünése) és a torlódás kialakulása között 
milyen alapon választható ki az a sűrűségi tartomány, amely a közúthálózat esetében az eltartóképességi határ ideális helyének tekinthető. Ennek meghatározására nem vállalkozunk, de a továbbiakban úgy tekintjük, hogy létezik ilyen pont.

\section{Visszatérés a fenntartható állapothoz - elméleti megoldási lehetőségek}

Mit lehet tenni, ha a kereslet meghaladja a rendelkezésre álló eltartóképességet, és szeretnénk visszatérni a fenntartható állapotokhoz? Az alábbiakban több szóba jövő irányt vázolunk fel: ezek rendre 1. az igények csökkentése, 2. a használat korlátozása (klubszolgáltatás bevezetése), 3. az elmozdulás a magán-közösségi sávon és 4. az eltartóképesség növelése.

1. Az IGÉNYEK CSÖKKENTÉSE • Egyik idetartozó lehetőség a közös javak fogyasztóinak a megállapodása, önkorlátozása: a legelöre csak adott számú állat hajtható ki, és ezt mindenki tudomásul veszi (4. ábra). Ilyenkor tulajdonképpen a felek a megtapasztalt véges készlet használatára korlátozzák a közös javak igénybevételét, és ezáltal a tiszta közjavakhoz hasonló állapotot teremtenek. Minél nagyobb a közösség, minél személytelenebbek a kapcsolatok, annál nehezebb ilyen jellegü belső megállapodást elérni (és különösen betartatni): egyelöre nem képzelhető el, hogy egy város lakosai és úthasználói megállapodjanak abban, hogy csak akkor használják az autóikat, ha az összes mozgásban lévő jármü száma kisebb, mint egy megadott érték - ami a gyakorlatban azt jelentené, hogy csak az indulhat útnak, akinek erre egy központi diszpécserszolgálat engedélyt ad. (Kicsit előreugorva az időben, egy önvezető jármüvekkel müködő városi rendszerben akár ehhez hasonló szabályozás már elképzelhető lehet!)

4. ábra

Igények csökkentése - önkorlátozás és hatása

Egymást nem akadályozzák

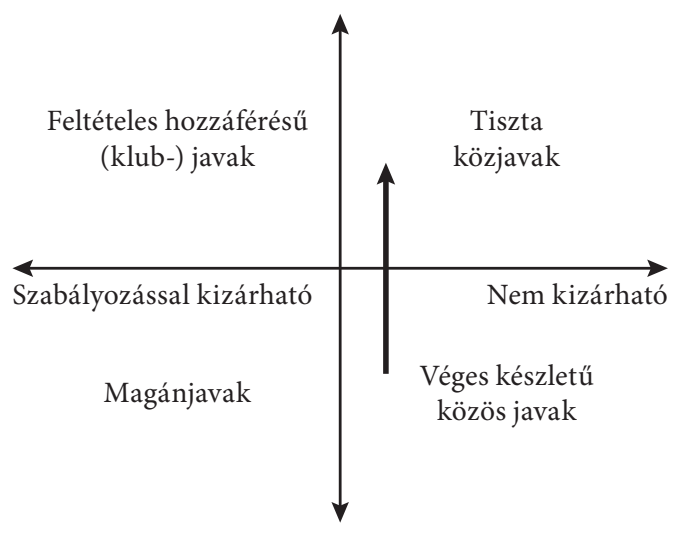

Egymást akadályozzák
Kereslet

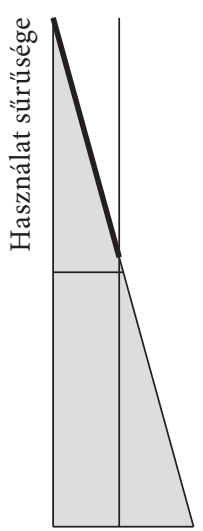

4.a)

Eltartóképesség határa

Fajlagos hozam Összes hozam

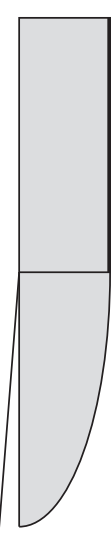

4.b)

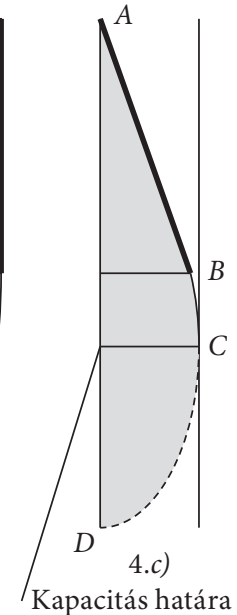

Forrás: saját szerkesztés. 
Az önkorlátozás tulajdonképpen az igények mennyiségi csökkentésének kizárólag a felhasználókra hárított és általában megfelelő ösztönzők hiányában kevéssé elvárható módja. Az igénycsökkentés kifinomultabb lehetőségeire még visszatérünk.

2. A használat korlátozása (KLubszolgáltatás bevezetése) • Ha a használók maguk között nem tudnak megállapodásra jutni, akkor külső szabályozáshoz kell folyamodni. Ilyenkor - feladva a kizárás tilalmát - kizárják azokat, akik a legjobban akadályozzák a többiek mozgását, vagy azokat, akiknek kizárásával a fenntartható állapot legnagyobb mértékben megközelíthető; de az is előfordulhat, hogy azokat zárják ki, akiknek a leggyengébb az érdekérvényesítő képességük. Ennek kereteit a feltételes hozzáférésű javak vagy klubjavak szolgáltatják, vagyis az 1. és a 2. ábrának az eddig részletesen nem tárgyalt, bal felső tartománya (5. ábra).

5. ábra

A hozzáférés korlátozása - feltételes hozzáférésű javak vagy klubjavak

Egymást nem akadályozzák

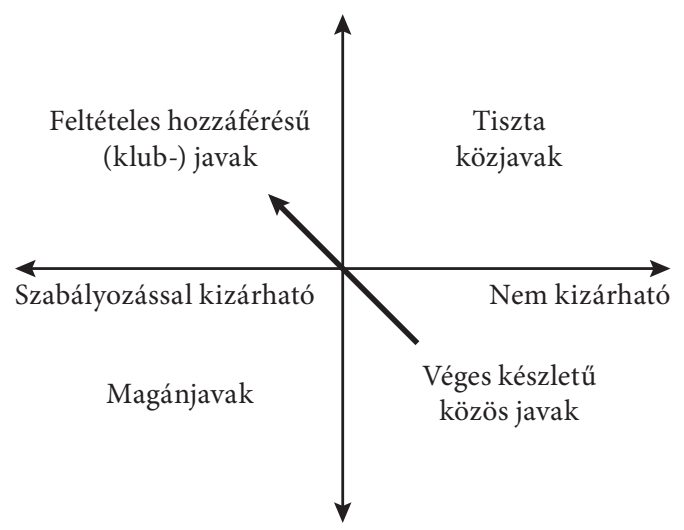

Egymást akadályozzák
Kereslet Fajlagos hozam Összes hozam

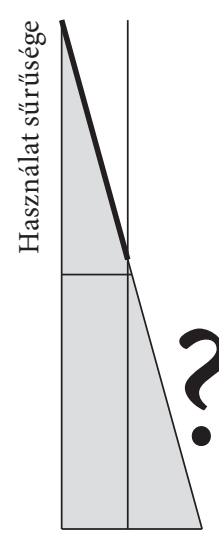

5.a)
Eltartóképesség határa

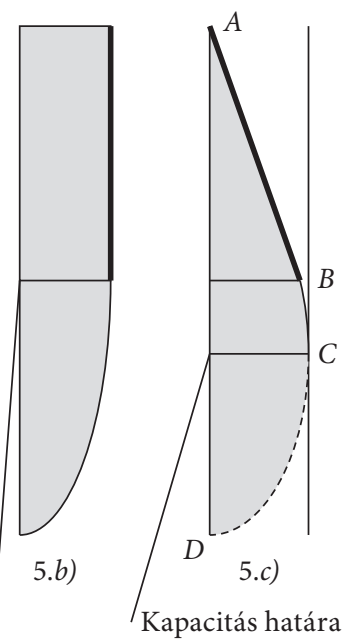

Forrás: saját szerkesztés.

A legkülönbözőbb javak (termékek és/vagy szolgáltatások) használatából koronként nagyon eltérő indokokkal lehetett kizárni potenciális használókat: így származás, nem, vallás, vagyoni helyzet stb. alapján. Napjainkban ennél kifinomultabb eszközök elfogadhatók: lehetnek deklarált jogosultságok (például behajtási engedély helyben lakóknak) vagy díffizetéssel megszerezhető hozzáférés (toll goods) - a közgazdasági irodalom nyomán itt mindkettőt klubjavaknak tekintjük (lásd Buchanan [1965/1992]). Így hozzáférést szerezhet, aki a jobb szolgáltatásért befizet egy bizonyos összeget (behajtási díj, autópályadíj stb.); aki eszközével teljesít bizonyos környezeti normákat (Euro 6 szabvány, elektromos hajtásmód stb.); vagy éppen, aki kevésbé pazarló a használata módjában (hárman ülnek a kocsiban, de idesorolható a közforgalmú közlekedés előnyben részesítése is - például a buszsáv). 
Minden kizárási követelménynek az a lényege, hogy a kizárások után a bennmaradtak számára biztosítani lehessen a megközelítően közjavak módjára történő szabad használatot, egymás akadályozásának a minimumra csökkentését. A gyakorlatban ez azt igényli, hogy a klubba belépők egyfelől fizessék meg azt a többletköltséget, amellyel a fenntartható müködésmódjuk biztosítható, másfelől számukra a kapott szolgáltatásnak meg kell érnie a klubba való bekerülés költségét.

Azok számára, akik a hozzáférést megszerezték, ilyen módon a működőképesség fenntarthatósága biztosított - a kizártak körülményeivel viszont értelemszerüen a klub nem foglalkozik. Ahhoz, hogy utóbbiak számára is fenntartható állapotok jöjjenek létre, külső (mind a tárgyalt klubon, mind pedig a klub igénybe vevőin kívüli) szabályozásra van szükség, olyanra, amelyik egyaránt tekintettel van a klubtagok és a kiszorulók körülményeire és érdekeire. Ha a klub létrejötte után a kizártak számára a müködésmód nem fenntartható, akkor ennek javításához újra számításba kell venni az itt tárgyalt lehetőségek valamelyikét (igénycsökkentés, újabb klub létrehozása, elmozdulás a magán-közösségi skálán, eltartóképesség növelése).

3. ElMOZDUlÁs A MAGÁN-KÖZÖssÉGI SÁvON • Feloldható-e a közös javak túlfogyasztása a közös jószág magánkézbe adásával (6. ábra, balra mutató nyíl)? Az eredeti közlegelöpéldában igen: ha a közlegelőt eleve felosztjuk a családok között, akkor minden család csak a saját területét tudja túllegeltetni, ez viszont nem áll érdekében, tehát nem fogja megtenni. Ugyanezt viszont nem tehetjük meg a városi közúthálózaton, ha ezt felosztanánk, és mindenki csak a saját háza előtt autózhatna, az egész hálózat elvesztené az értelmét. A legelő bármelyik parcellájában lévő fü egyenértékü, azonban a közúthálózatnak csak összefüggően van értelme, egyes darabjai külön-külön nem töltik be a funkciójukat.

6. ábra

Elmozdulás a magánjavak-közösségi javak skáláján

Egymást nem akadályozzák

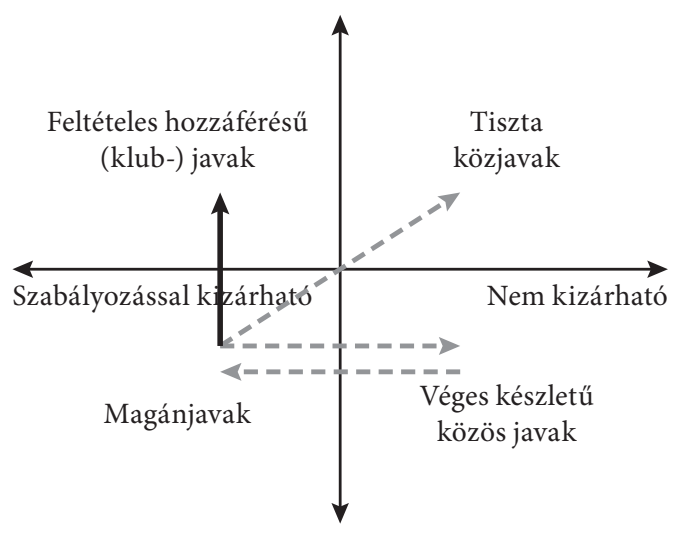

Egymást akadályozzák
Kereslet Fajlagos hozam Összes hozam

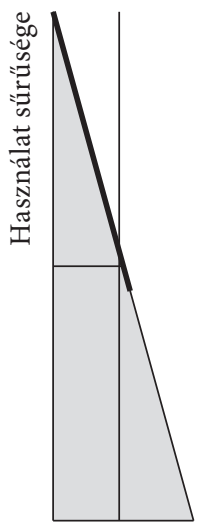

6.a)

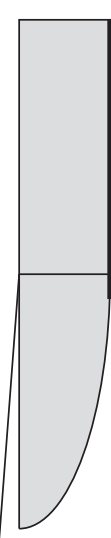

6.b)

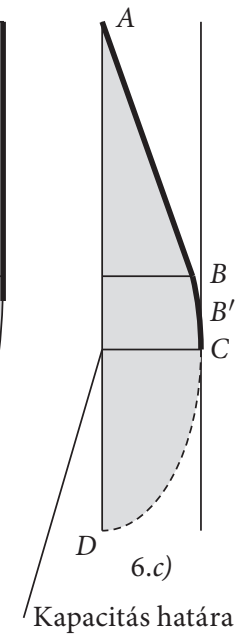

Forrás: saját szerkesztés. 
A magánjószág-közös jószág skálán tehetünk egy ellenkező irányú lépést is. Ne a legelőt daraboljuk fel, hanem a magántulajdonban lévő teheneket vegye a falu közös, mondjuk, szövetkezeti kezelésbe. A korábbi tulajdonosok ekkor már nem a saját tehenük hozamában, hanem az összes hozam rájuk jutó részében válnak érdekeltté: ezért, ha nem is feltétlenül a hosszú távú fenntarthatóságot, de legalább az összes hozam maximalizálását fogják szorgalmazni, és a legelő $C$ pontot meghaladó igénybevételétől mindenképpen tartózkodni fognak. Így a véges készlettel rendelkező közlegelő közös hasznosítása jön létre a magánalapú hasznosítás helyett.

Ez a lépés már átvihető a városi közúthálózat esetére is: ott azt jelenti, hogy a közúthálózaton közjárműveket használunk, azaz a közforgalmú és megosztott jármüflotta használatához érkeztünk (egyelőre az elmélet szintjén). Értelemszerüen nem a torlódott közös tulajdonú használatot, nem is a korlátlan (tiszta) használati lehetőséget (vékony, szaggatott nyilak), hanem az akadályoztatást elkerülő használati módot kívánjuk elérni, ami klubjavak formájában üzemeltetett jármüflotta segítségével érhető el reálisan. Ezt a 6. ábra folytonos vastag nyila érzékelteti.

4. Az ELTARTóKÉPESSÉG NÖVELÉSE - Ilyenkor a növekvő igények biztosítására az igényekkel szemben érvényesülő korlátot (az eltartóképesség határát) próbáljuk meg eltolni (7. ábra) a $B$ pontból egy $B$ ' pontba. Ilyesmi történt akkor, amikor - a 20. század második felében - egyre jobban bővült a közúti sávok száma, ezzel növelve az autók számára rendelkezésre álló tér méreteit. (Tulajdonképpen a város gépkocsieltartó képességét növelte az ilyen beavatkozás.) Ami azonban a közút felől nézve bővülés, az a városi közterület összességét tekintve kizárás: hiszen az intézkedés a közút által elfoglalt területről egyúttal kizárja a korábban ott lévő zöld területet, fasort, gyalogosjárdát, villamosperont, esetenként magát a felszínen közlekedő villamost vagy a helyszínen megállni kívánó autóst is (sőt néha a közterületen kívül is kizár előkerteket, lakóépületeket, kereskedelmet).

Ma már látjuk, hogy a modernizációs városfejlesztés nem gondoskodott a kizárt funkciók megfelelő ellátásáról, a városi életkörülmények fenntartható egyensúlyának biztosításáról. Sőt paradox módon a közút iránti igényeknek megfelelni próbáló bővítések ellenére a gépjármüforgalomban is fennmaradtak - esetleg éppen a javuló körülmények nyomán generált kereslet hatására újra kialakultak - a torlódások. Rá kellett ébredni arra, hogy a közúti torlódást, a rendelkezésre álló kapacitás túllépését nem a zöld felületek, nem a fák, nem a villamosok, nem a gyalogosok és nem is a házak okozzák, hanem a többi gépkocsi. A sávbővítés, a közúti kapacitások növelése ugyanis megerősítő jelzést ad a gépkocsi városi használatára, és hozzájárul ahhoz, hogy egyre több ember tekintse magától értetődő követelménynek, hogy a városnak biztosítania kell számára a mindennapi autózása feltételeit. 
7. ábra

Eltartóképesség növelése

Egymást nem akadályozzák

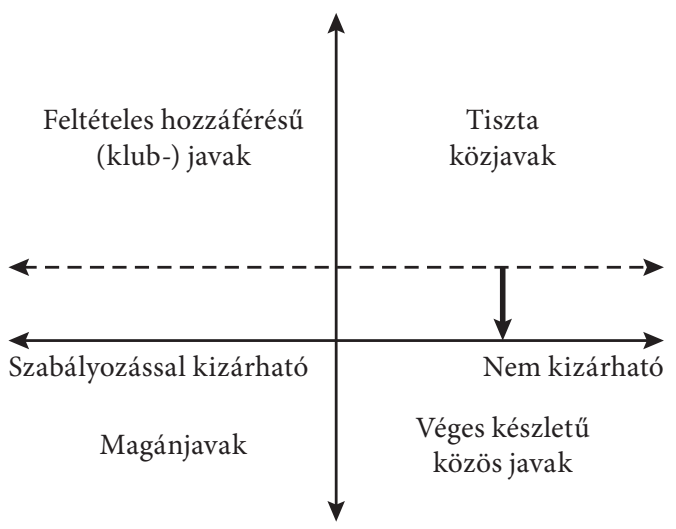

Egymást akadályozzák
Kereslet Fajlagos hozam Összes hozam

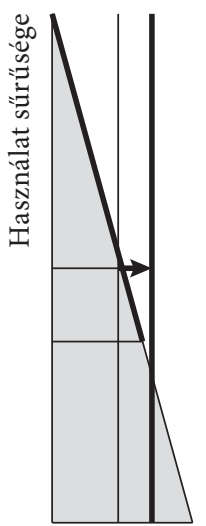

7.a)

Eltartóképesség határa

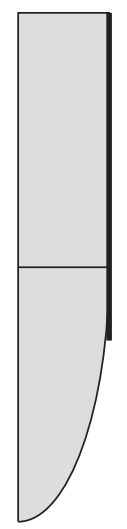

7.b)

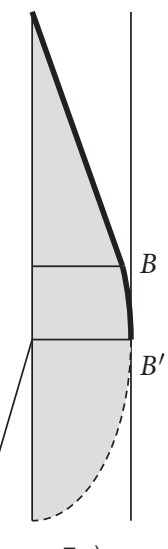

7.c)

Forrás: saját szerkesztés.

\section{A fenntartható városi mobilitás felé}

A fenntartható városi mobilitás számos tényezője közül az alábbiakban csupán az eddig tárgyaltakból következő - a városi közterület használatával összefüggő - kérdésekre térünk ki.

A fent tárgyalt 4 . irány, azaz további közúti területek birtokbavétele más városi funkciók visszaszorítása árán, nem járható. Ennek belátásához szükségünk van a leírt dinamikus folyamat megértésére és a zsákutca felismerésére. Nem a gépkocsi, azaz egy eszköz számára (és nem is csak a gépkocsi-tulajdonosok), hanem a városban élő emberek összessége számára kell élhetővé, használhatóvá, vonzóvá, egészségessé, kényelmessé tenni a városi életet. Az egyensúly megteremtése érdekében éppen a legzsúfoltabb központi területeken vissza kell venni az autók rendelkezésére bocsátott felületekből, és újra fel kell azt osztani, körültekintően méltányolva valamennyi városi résztvevő igényeit. Formálisan ez a rendelkezésre álló terület bővítését jelenti a gyalogosfelületek, a zöld területek, az egyéni lágy közlekedési eszközök (kerékpár, roller stb. és ezek elektromos változatai) és a közforgalmú közlekedés számára, azaz éppen a fordítottját annak a folyamatnak, ami a 20. század második felében végbement.

Önmagában ettől azonban még nem válik a mobilitási rendszer egésze fenntarthatóvá, csak az elkövetett túlkapásokat lehet így visszafordítani a motorizáció számára biztosított felület rovására. A közterület újraosztásával egy időben azt is biztosítani kell, hogy az autóközlekedést szolgáló csökkenő felületen ne a torlódások növekedése kényszerítse más választásra az eddig gépkocsit használókat, hiszen ez 
egyáltalán nem lenne fenntartható - társadalmi, gazdasági, környezeti szempontból elfogadható - megoldás.

Az igények méltányos eljárással való befolyásolásának számos lehetősége van, erről jó áttekintések születtek (Orosz-Pásti [2002], Juhász [2013]). Juhász [2013] egyrészt a közlekedés módjának befolyásolásával (például gyalogosfelületek, kerékpársávok, $\mathrm{B}+\mathrm{R}$, buszsávok, bérletárak, jármümegosztó klubok, telekocsisávok, parkolási díjak, területi kvóták, behajtási díjak); másrészt az igények térbeli és időbeli befolyásolásával (például csillapított forgalmú zónák, hídvám, tervezett késleltetés, csúcsidőben drágább közforgalmi jegyár, időben változó útdíj) oldaná meg a problémát. A fenti blokkokban összefogott eszközök többsége tulajdonképpen klubjószág (annak engedélyhez kötött vagy díjfizetéses) formájában kezeli a túlterhelt városi térség gyalogos- és jármüforgalmát.

Olyan összetett és átgondolt szabályozásra van szükség, amelyik nemcsak a klubba bekerülö forgalom számára biztosítja a fenntartható müködést, hanem a kiszorított szereplők számára is. Ez közvetlenül kétirányú intézkedéscsomagot jelöl ki. Egyfelől azok számára, akik feladják a gépkocsi használatát, biztosítani kell a kedvező alternatív közlekedési módokat (a közforgalmú közlekedés, továbbá a kerékpár és vele rokon eszközök rendelkezésére álló felület kialakítása/növelése). Másfelöl azokon a területeken, ahová maguk a gépkocsik szorulnának ki, szintén gondoskodni kell a torlódás megelőzéséről. Ez utóbbit területileg és időben is differenciált behajtási díj bevezetésével lehet elérni, az ennek megfelelő árazást pedig éppen a tapasztalatok követésével lehet fokozatosan beállítani.

Az eddig leírt beavatkozási módszerek alapvetően adottnak tekintik a forgalmi igények mennyiségét, és azok térbeli, időbeli terelésén, valamint a közlekedési mód befolyásolásán keresztül fejtik ki a hatásukat. Ennél sokkal nagyobb tartalékok rejlenek ugyanakkor a forgalmi igények csökkentési lehetőségeiben. Ilyenkor tehát a 4. ábrán bemutatott hatást kívánjuk elérni különböző intézkedések segítségével.

A mennyiségi igények csökkentése elvben elérhető lenne a korábban már említett önkorlátozáson keresztül. A gyakorlatban azonban nem várható, hogy az emberek hirtelen maguktól a korábbi szokásaiktól gyökeresen eltérő módon kezdjenek viselkedni. Olyan ösztönző szabályozásra (esetenként közlekedésen kívüli megoldásra) van szükség, amely az elvárt választást az egyének számára is kívánatossá, vonzóvá teszi. A már idézett Juhász [2013]-ban ez a beavatkozások harmadik blokkja: a célpontok elhelyezkedésének és az utazások gyakoriságának a befolyásolása (idetartozik a várostervezés, továbbá a munkaszervezés, munkaidő-beosztás számos eszköze).

Az általunk már tárgyalt lehetőségek közül a torlódás is változtatásra ösztönöz, de az ezen keresztül történő szabályozás egyrészt nyilvánvalóan nem elfogadható (veszélyes, kényelmetlen, frusztráló, szennyezö), másrészt nem is hoz létre stabil javulást, mert a körülmények átmeneti javulása után rövidesen visszaáll az elkerülni kívánt állapot. A klubjószág létrejöttét támogató intézkedések közül a több utast szállító jármü előnyben részesítése és általában a jármümegosztásra történő ösztönzés elfogadható módon segíti elő a gépjárműforgalom mennyiségének a csökkentését. Ahogy láttuk, ekkor tulajdonképpen a közterület magánhasználatától közelítünk a közterület szervezett közösségi használata felé. A szervezettség 
fokozásával és a célfüggvény helyes megválasztásával - az utóbbinak megfelelő ösztönzés kialakításával - állítható be, hogy a hálózaton a kapacitáskihasználásból kiinduló szabályozás helyett a hosszú távon fenntartható használat szempontjait tekintsük elérendő célnak.

Hosszabb távon a nagyobb távolságú utazási, szállítási igényeket csökkenti a szolgáltatások szerkezetének, illetve a város szerkezetének megváltoztatása a városi alközpontok erösítésével - növekvő számú szolgáltatás helyben való elérhetőségét biztosítva. Ez nem gyors folyamat, de ahogy korábban a növekvő autóhasználat a helyi utcákból a nagyobb központok terelte a városi szolgáltatásokat, a fordított irányú folyamatban sürüsödhetnek a helyi célpontok, amelyek megközelítéséhez kevesebbet kell közlekedni. Nemcsak a kereskedelmi szolgáltatások térbeli szerkezetére igaz, hanem a közforgalmú gerinchálózatok átszállási pontjainak térszerkezetére is, hogy ha azok mind a városközpontban koncentrálódnak, akkor növelik a belső és a külső területek közötti különbséget, és rontják távolabbi alközpontok megerősödésének az esélyeit. Hasonlóképpen a városi úthálózat szerkezete is jelentős befolyást gyakorol arra, hogy létrejönnek-e szoros kapcsolatok szomszédos külső térségek között, erősödő helyi központokkal, vagy pedig ez a hálózat is az egy központú szerkezetet tartósítja, és tovább növeli a város belső és külső részei közötti fejlettségi különbségeket.

Az utazási igények csökkentésének további lehetőségei a közlekedés működési rendszerének fejlesztésében rejlenek. A következőkben azt vizsgáljuk, hogy a technológiai újdonságok elterjedésének szabályozása hogyan segíti a közterület fenntartható használatának szakpolitikai célját és a fenntartható mobilitási szolgáltatásokat.

Bár a vasút, a villamos vagy a trolibusz régóta elektromos meghajtásúak, az elektromos autó mégis az új fejlesztések homlokterébe került. Hozzájárul ehhez a ráragasztott „nulla kibocsátás” címke is, ami alapvetően hamis. Nem vitatva a helyi légszennyezés csökkentésének a fontosságát vagy a mérséklődő zajszennyezés tényét, nyilvánvaló, hogy a légszennyezés továbbra is létrejön, csak áthelyeződik az elektromos áram előállítási helyére, nyilván az ott használt energiahordozótól függő mértékben. Emellett a helyi légszennyezés nemcsak az üzemanyag elégetéséből származik, de jelentős részben a gumiabroncs kopásából és a fékbetétek elhasználódásából is, ami az elektromos autónál is probléma. Ezen túlmenően a térszennyezést, azaz a gépkocsinak a városi torlódásokat előidéző szerepét az elektromos autó egyáltalán nem csökkenti, sőt az a tény, hogy a használója zöld besorolást, adókedvezményt, olcsó áramot kap, kifejezetten ösztönzi a gépkocsi városi használatát. Nem arról van szó, hogy az elektromos autó fejlesztése káros lenne, vagy elterjedését akadályozni kellene, de egy komplex összefüggésekkel nem számoló ösztönzési program még az egyébként hasznos fejlesztések következményeit is képes kedvezőtlen irányba mozdítani.

Az új közlekedési technológiák másik főszereplöje az önvezető jármü. Fontos jellemzője, hogy fejlesztésének elindítója nem a gyorsabb, nagyobb, erősebb közlekedési eszköz kialakítása iránti igény volt, hanem az egyre több közlekedésbiztonsági és vezetéskényelmi felszereléssel ellátott járművek létrehozása. Ezért is, valamint azért, mert a társadalmi vitákban is középpontba kerültek e jármü használatának 
a közlekedésbiztonsági szempontjai, bizonyosra vehető, hogy jelentős előrelépést, áttörést fog jelenteni a - jelenleg a vezető halálokok között számon tartott - közlekedés baleseti és biztonsági mutatóinak a javításában. Másrészt a fejlesztés kulcsa nem egyszerủen az önvezető autó, ${ }^{3}$ hanem az egymással is kommunikáló önvezető jármủvek hálózati irányítása, azaz a technológiának a szervezésben és a folyamatirányításban való felhasználása. Végül is az önvezető autó utasa ugyanannyira a városi diszpécserközpontból irányított közlekedési áramlás passzív szereplöje lesz, amenynyire a közösségi közlekedés utasai azok. Következésképpen a mainál sokkal kisebb lemondást fog jelenteni az egyéni autóhasználat feladása, a megosztott autó, kisbusz, busz stb. használata. Lényegében egy közös hálózati rendszer használatával el fog mosódni az egyéni és a közösségi közlekedés közötti éles határvonal.

\section{A változás jelei}

Fleischer [2019] már utalt azokra a jelekre, amelyek a mai közlekedésben is felhívják a figyelmet a megindult változásokra és a forgalom csökkentésében rejlö tartalékokra. A londoni Cityben, azaz London három négyzetkilométeres belvárosi területén 1999 és 2017 között 59 százalékkal csökkent a személygépkocsik és taxik forgalma, és a reggeli és délutáni csúcs többletforgalma lényegében teljesen átterelödött a kerékpárra és a gyalogosforgalomra (City of London [2018]). Az Île de France területén, azaz Párizs régiójában végzett felmérés alapján a régióban regisztrált gépkocsik 60 százaléka a vizsgált nap folyamán meg sem mozdult, a többinek pedig a kétharmad része egy rövid út megtétele után valahol máshol állt. Egyetlen negyedórában sem mozgott egy időben több jármü, mint a teljes állomány 12 százaléka (Direction Régionale [2013], Vitézy [2018]).

Az ITF [2016] beszámol arról a modellkísérletről, amelyben megvizsgálták, hogy a kimutatható tartalékok mennyiben használhatók fel jármümegosztás segítségével a forgalom csökkentésére. A Lisszabon 2010-es tényadatain alapuló számításban az volt a kiinduló feltevés, hogy valamennyi városi közlekedési igény kielégíthető magánautók nélkül, megosztott taxik, továbbá nyolc- és tizenhat üléses megosztott buszok használatával. Ezen túlmenően csak a város metróhálózatát és a vasúti, elővárosi hálózatát vették figyelembe megmaradó kapacitásként. A kapott eredmény szerint a mai gépkocsiállomány 3 százaléka elegendőnek bizonyult a forgalom lebonyolítására, értelemszerüen jelentős futásteljesítménnyel, de így is megtakarítva a kibocsátás és az energiafelhasználás egyharmadát. A közparkolók területének 95 százaléka lenne felszabadítható, a közlekedés költségei a felére csökkenhetnek. A számítás szerint a torlódások megszünnének, ezáltal a megteendő útszakaszok időigényének a szórása jelentősen csökkenne. A városon belül térben is kiegyenlítődne az elérhetőség (a 30 percen belül elérhető szolgáltatásokat vették figyelembe), azaz mindenhol biztosíthatóvá válna az a szolgáltatási szint, amelyben jelenleg csak a város tizede részesül.

\footnotetext{
${ }^{3}$ Annak terjedése önmagában akár egy fő alá csökkentheti a ma is alacsony egy gépkocsira jutó foglaltságot!
} 
Mindezek együttes hatásaként, vagyis a hálózati szinten optimalizált (elektromos, önvezetö, biztonságos, az utasok úticélját egyenként számontartó) rendszerben várakozásunk szerint megvalósítható a városi közterületet is takarékosan használó közlekedés. Fenntarthatóságát a felsorolt technikai háttér mellett az biztosítja, hogy célfüggvénye nem az egyedi utak időveszteségének a minimalizálása lesz, hanem a teljes rendszer stabilitásának a fenntartása és ezzel az egyes utak időtartama időbeli szórásának a lecsökkentése. ${ }^{4}$ Azt várjuk, hogy a résztvevők számára a hektikus és véletlenszerü hatások kiküszöbölése révén a megbízhatóbb és kiszámíthatóbb utazás csökkenteni fogja a közlekedéshez ma társuló idegességet, sietséget és konfliktusokat.

\section{Összefoglalás}

A fenntartható városi közlekedés megteremtésének és szolgáltatás formájában való kezelésének fontos eleme, hogy - a közlekedés technológiai lehetőségei mellett a szabályozási módszerek fejlesztésében, továbbá a társadalmi elvárások befolyásolásában rejlő lehetőségeket és korlátokat is módszeresen feltérképezzük és figyelembe vegyük. A tanulmányban a városi közterületre mint közjószágra tekintettünk, és ebben a keretben elemeztük az elörelépés módjait.

A közjavakat a szakirodalomban leginkább elfogadott két kritérium alapján definiáltuk: a közjavak igénybevevői 1. a használatból szabályozással nem zárhatók ki, és 2. használatukkal egymást nem akadályozzák. Ennek megfelelően - a magánjavakon kívül - a közjavak három tartományát lehet megkülönböztetni: 1. a tiszta közjavakat, 2. a véges készlettel rendelkező közös javakat és 3. a feltételes hozzáférésü (vagy klub-) javakat. Az akadályoztatási kritériumot a kereslettel arányos, folytonos sürűségskálán lehet vizsgálni. A kételemü igen/nem felosztás helyett fontos megkülönböztetni az eltartóképességi határt kijelölő, továbbá a hozammaximumot kijelölő pontokkal elhatárolható szakaszokat. E referenciapontok figyelembevétele egyben a hosszú távon fenntartható müködést, illetve a hozammaximalizálást célzó müködést is megkülönbözteti.

Az így felépített modell alkalmas arra, hogy tárgyalási keretet adjon a fenntarthatatlan városi közterület-használat fenntarthatóvá tételéhez szükséges lépések leírásához. E modell segítségével értékeltük a - mértékében adottnak tekintett - igények befolyásolási módszereit (alternatív közlekedési módok, az igények térbeli, időbeli áthelyezése); az eltartóképesség növelésére irányuló törekvéseket; továbbá az igények mennyiségi csökkentésének a lehetőségeit (térbeli, városszerkezeti beavatkozások és a közösségi megosztás irányába mozdulás a magán- és a közfogyasztás tengelyen).

Külön kitértünk a tanulságok alapján két technológiai „slágertéma”, az elektromos jármü és az önvezető jármủ várható szerepére a fenntartható közlekedésben. $\mathrm{Az}$ elektromos gépkocsi a deklarált és elismert hasznai mellett a városi területhasználat

\footnotetext{
${ }^{4}$ Ez a törekvés teljes összhangban van a közlekedés megbízhatóságát előtérbe helyező, illetve a pontatlanság gazdasági hatásait bemutató nemzetközi és hazai vizsgálatokkal (lásd ITF [2010] és Juhász és szerzőtársai [2017]).
} 
szempontjából semmivel nem elönyösebb, mint a hagyományos jármü, ezáltal az egyoldalú támogatása a fenntarthatóság ellenében hat. Az önvezető jármü esetében a fenntarthatóság szempontjából nagyobb jelentősége van a hálózatban történő kommunikációnak és szervezhetőségnek, mint az egyedi jármüre vonatkozó eredményeknek. A mobilitási előnyöket a szervezett, integrált városi közlekedési rendszer keretében nyújtott szolgáltatás tudja biztosítani.

\section{Hivatkozások}

Brundtland-Bizottság [1988]: Közös jövőnk. A Környezet és Fejlesztés Világbizottság jelentése. (Szerk. Persányi Miklós.) Mezőgazdasági Könyvkiadó, Budapest. Eredeti megjelenés: Our Common Future. Report of the World Commission on Environment and Development. Oxford University Press, New York-Oxford.

Buchanan, J. M. [1965/1992]: A klubok közgazdasági elmélete. Megjelent: Buchanan, J. M.: Piac, állam, alkotmányosság. Közgazdasági és Jogi Könyvkiadó, Budapest, 132-147. o.

City of London [2018]: Traffic in the City 2018. Strategic Transportation Department of the Built Environment, City of London, http://democracy.cityoflondon.gov.uk/documents/ s91800/Appendix\%201\%20-\%20Traffic\%20in\%20the\%20City\%202018.pdf.

Direction Régionale [2013]: Motorisation et usage de la voiture en Île-de-France. Enquête globale transport. Direction Régionale et interdépartementale de l'Équipement et de l'Ameénagement d'Île-de-France, Service de la Connaissance des Études et de la Prospective, http://www.driea.ile-de-france.developpement-durable.gouv.fr/IMG/pdf/EGT_ Motorisation_et_usage_de_la_voiture_en_Ile-de-France_cle17ce43.pdf.

Fleischer TAmás [2019]: A mobilitási szolgáltatások fenntarthatósági kérdései: társadalmi hatások, tér- és időgazdálkodás. Közlekedéstudományi Szemle, 69. évf. 1. sz. 49-58. o.

Hardin, G. [1968]: The Tragedy of the Commons. Science, New Series, Vol. 162. No. 3859. 1243-1248. o. https://doi.org/10.1126/science.280.5364.682.

Highway Capacity Manual [2000]: Highway capacity manual. Transportation Research Board, National Research Council, Washington, DC, https://sjnavarro.files.wordpress. com/2008/08/highway_capacital_manual.pdf.

ITF [2010]: Improving Reliability on Surface Transport Networks. International Transport Forum, OECD Publishing, http://www.oecd-ilibrary.org/transport/improving-reliabilityon-surface-transport-networks_9789282102428-en.

ITF [2016]: Shared Mobility. Innovation for Liveable Cities. OECD International Transport Forum, https://www.itf-oecd.org/sites/default/files/docs/shared-mobility-liveable-cities.pdf.

Juhász Mattias [2013]: Travel Demand Management. Possibilities of influencing travel behaviour. Periodica Polytechnica Transportation Engineering, Vol. 41. No. 1. 45-50. o. https://doi.org/10.3311/pptr.7096.

Juhász Mattias-Mátrai Tamás-Koren Csaba [2017]: Forecasting Travel Time Reliability in Urban Road Transport. Archives of Transport, Vol. 43. No. 3. 53-67. o. https://doi. org/10.5604/01.3001.0010.4227.

Motorway Design... [2017]: Motorway design guide. Capacity and flow analysis 2017. Transport, Roads and Maritime Services, NSW Australia, http://www.rms.nsw.gov.au/ business-industry/partners-suppliers/documents/motorway-design/motorway-designguide-capacity-flow-analysis.pdf. 
Mozsár Ferenc [2004]: A közjavak magánkereslete. Doktori értekezés. Szegedi Tudományegyetem, Közgazdaságtani Doktori Iskola, Szeged, http://doktori.bibl.u-szeged.hu/321/1/ de_2931.pdf.

Orosz Csaba-PÁsti Balázs [2002]: Kielégíthetetlen közlekedési kereslet. Fejlesztési és finanszírozási lehetőségek Budapesten - útdíjakkal vagy nélkülük? Városi Közlekedés, 42. évf. 4. sz. 231-235. o.

Ostrom, E. [2005]: Understanding Institutional Diversity. Princeton University Press, Princeton, NJ.

Samuelson, P. A. [1954]: The Theory of Public Expenditure. Review of Economics and Statistics, Vol. 36. No. 4. 386-389. o. https://www.jstor.org/stable/1925895.

TodTs, W. (szerk.) [2018]: $\mathrm{CO}_{2}$ emissions from cars: The facts. European Federation for Transport and Environment (AISBL), Brüsszel, https://www.transportenvironment.org/sites/te/files/ publications/2018_04_CO2_emissions_cars_The_facts_report_final_0_0.pdf.

VITÉZy DÁvid [2018]: A jövő városának közlekedése - veszélyek és lehetőségek. Előadás. Infotér, https://www.youtube.com/watch?v=r3NCUhFsKLs. 